\title{
Reducing the impact of condensed tannins in a diet based on carob pulp using two levels of polyethylene glycol: lamb growth, digestion and meat quality
}

\author{
Alessandro Priolo ${ }^{*}$, Massimiliano LANZA a , Marco Bella ${ }^{\mathrm{a}}$, \\ Pietro PENNISI ${ }^{\mathrm{a}}$, Venera FASONE ${ }^{\mathrm{b}}$, Luisa BIONDI ${ }^{\mathrm{a}}$ \\ aUniversity of Catania, DACPA Sezione di Scienze delle Produzioni Animali, Via Valdisavoia 5, \\ 95123 Catania, Italy \\ bUniversity of Reggio Calabria, Dipartimento di Scienze e Tecnologie Agro-forestali e \\ Ambientali, Reggio Calabria, Italy
}

(Received 7 February 2002; accepted 19 September 2002)

\begin{abstract}
Fourteen male Comisana lambs were divided into two groups of seven at age 45 days and were fed a diet containing 56\% of dried carob pulp (as fed basis). One group (P10) received a supplement of $10 \mathrm{~g}$ of polyethylene glycol (PEG) for each $\mathrm{kg}$ of diet, while the second group (P40) received a supplement of $40 \mathrm{~g}$ of PEG for each $\mathrm{kg}$ of diet. Both diets were ground and supplied ad libitum. The experimental diet contained $2.1 \%$ of condensed tannins $(\mathrm{CT})$ on a dry matter basis. The lambs fed the P40 diet had higher average daily gain than the P10 lambs $(P<0.05)$ and obtained higher live weights at slaughter $(P=0.08)$ although the dry matter intake was not different between the treatments. The increased level of PEG (P40 vs. P10 lambs) increased dry matter digestibility $(P=0.07)$ and nitrogen $(\mathrm{N})$ and neutral detergent fibre (NDF) digestibility $(P<0.01)$. The carcasses from the $\mathrm{P} 40$ lambs were heavier and fattier than those from the P10 lambs $(P<0.05)$. Meat $(l$. dorsi muscle) from the P10 lambs showed higher $(P<0.05)$ values of lightness $\left(\mathrm{L}^{*}\right)$ compared to the $\mathrm{P} 40$ lambs. No differences in eating quality were registered among the groups. These results indicate that in a diet based on carob pulp (56\%), $10 \mathrm{~g}$ of PEG per kg of diet are not sufficient to eliminate the effects of CT.
\end{abstract}

carob pulp / meat quality / polyethylene glycol / sheep / tannins

Résumé - Réduction de l'impact des tannins condensés dans un régime à base de pulpe de caroube en utilisant deux niveaux de polyéthylène glycol : croissance des agneaux, digestion et qualité de la viande. Quatorze agneaux mâles de race Comisana ont été séparés à l'âge de 45 jours en deux groupes de sept individus, et ont reçu un régime contenant $56 \%$ de pulpe de caroube. Un groupe (P10) a reçu un supplément de $10 \mathrm{~g}$ de polyéthylène glycol (PEG) par kg de ce régime, tandis que le

*Correspondence and reprints

Tel.: +39 095 234331; fax: +39095 234345; e-mail alessandro@mbox.fagr.unict.it 
second groupe (P40) en a reçu $40 \mathrm{~g} \cdot \mathrm{kg}^{-1}$. Dans les deux cas, le régime expérimental était broyé et distribué ad libitum aux animaux. Il contenait $2,1 \%$ (de la matière sèche) de tannins condensés (CT). Les agneaux P40 ont eu un gain moyen quotidien plus important que les agneaux $\mathrm{P} 10(P<0,05)$ et un poids vif à l'abattage également supérieur $(P=0,08)$, malgré une ingestion en matière sèche similaire entre traitements. Avec l'augmentation du niveau de PEG (agneaux P40 vs. P10), la digestibilité de la matière sèche a légèrement augmenté $(P=0,07)$, tandis que celles de l'azote et du NDF se sont accrues de façon plus marquée $(P<0,01)$. Les carcasses des agneaux P40 étaient plus lourdes et plus grasses que celles des agneaux P10 $(P<0,05)$. La viande de ces derniers (muscle $l$. dorsi) montrait des valeurs de luminosité supérieures à celle des agneaux $\mathrm{P} 40(P<0,05)$. En revanche, leur qualité sensorielle ne semblait pas différente. Ces résultats indiquent qu'avec un régime à base de pulpe de caroube (56\%), un supplément de $10 \mathrm{~g}$ PEG $\cdot \mathrm{kg}^{-1} \mathrm{n}$ 'est pas suffisant pour éliminer les effets des tannins condensés.

pulpe de caroube / qualité de la viande / polyéthylène glycol / mouton / tannins

\section{INTRODUCTION}

One of the main problems of the use of carob pulp for ruminant feeding is the presence of condensed tannins (CT) [14] that are phenolic compounds present in several legume forages and tree leaves and pods [3, 18]. Although several nutritional advantages were described when $\mathrm{CT}$ from some plant species were present up to $4 \%$ of the dry matter in sheep diets $[2,17]$, in a preceding paper [11] we found that $2.5 \%$ of CT in a diet containing carob pulp had deleterious effects on lamb growth and meat quality. This happened because CT link with and precipitate proteins in the rumen [7], reducing protein availability for ruminal micro-organisms. CT may also inhibit absorption from the intestine [18].

Polyethylene glycol (PEG) reacts preferentially with CT and prevents the formation of tannin-protein complexes [7] and therefore it has been used to eliminate CT effects for both experimental or production practices $[15,18]$. In the preceding trial [11], PEG was used to eliminate the impact of CT from carob pulp. The quantity of PEG given corresponded to 1.8 times the CT content of the diet. Considering the high cost of PEG, the objective of this trial was to study the possibility of reducing the PEG given to sheep fed a diet similar to that used by Priolo et al. [11] and to evaluate the effects on lamb growth, digestion and carcass and meat quality.

\section{MATERIALS AND METHODS}

\subsection{Animals and diets}

Fourteen male Comisana lambs born on the same farm were weaned and randomly divided on the basis of live weight into two groups of seven at age 45 days and allotted into individual pens. The animals were adapted to the experimental diets during a 5 -d period. From age 50 days (experimental day 1), both groups of lambs received the same diet containing $56 \%$ of dried carob pulp, $26.1 \%$ of alfalfa hay, $15 \%$ of soybean meal, $1 \%$ of urea, and a mineral/vitamin mixture (Tab. I). One group (P10) received $10 \mathrm{~g}$ of PEG (molecular weight 4000) added for each $\mathrm{kg}$ of the diet, in an as fed basis, while the second group (P40) received $40 \mathrm{~g}$ of PEG for each $\mathrm{kg}$ of the diet. The diets were ground and passed through a 5-mm screen. Lambs had ad libitum access to the diets (fresh feed was supplied every day at 09.00) and to water. Refusal was removed and weighed daily to calculate voluntary feed intake. 
Table I. Ingredients and chemical composition of the diets ${ }^{1}$.

\section{Ingredient ( $\%$ as fed)}

Alfalfa hay

26.1

Soybean meal

Carob pulp

Urea

$\mathrm{NaCl}$

Vitamin/mineral premix

$\mathrm{CaCO}_{3}$

\section{Chemical Composition (\% of DM)}

DM

Hemicellulose

Cellulose

ADL

Acid insoluble ash

Protein-bound CT

Fibre-bound CT

Total CT

\footnotetext{
${ }^{1}$ The P10 group received the diet with $10 \mathrm{~g}$ of polyethylene glycol added for each $\mathrm{kg}$ of the diet; the P40 group received the diet with $40 \mathrm{~g}$ of polyethylene glycol added for each $\mathrm{kg}$ of the diet.

DM: dry matter, NDF: neutral detergent fibre, ADF: acid detergent fibre, ADL: acid detergent lignin, CT: condensed tannins.
}

\subsection{Animal measurements}

All lambs were weighed at 09.00 once a week, before removing refusals and supplying fresh feed. Harnesses for faecal collection were placed on the lambs on experimental day 28. The lambs were adapted to the harnesses for 2 days; from experimental day 30 to day 37 of the experimental period, the faeces were collected into bags and removed once daily, weighed and a subsample of $10 \%$ was composited per animal to determine the digestibility of dry matter (DM), nitrogen (N) and neutral detergent fibre (NDF). Calculation of dry matter digestibility was done after subtracting the daily intake of PEG from faecal DM [11].

\subsection{Slaughter procedures and carcass classification}

The animals were slaughtered at age $100 \mathrm{~d}$. Slaughtering took place after electrical stunning, by exsanguination. The digestive tract content was removed and weighed to calculate the empty live weight. Immediately 
after slaughter the carcasses where weighed and classified for fatness using a 15-point scale [5]. Six hours after slaughter the carcasses were placed in a refrigerated room set to $4{ }^{\circ} \mathrm{C}$.

\subsection{Feed and faeces analyses}

Offered and refused feed and faeces were analysed for fibre fractions [6] and for crude protein [1]. Condensed tannins were determined by a butanol/HCl method as described by Terrill et al. [16] to indicate total, free and bound CT. The standard was obtained from Lotus pedunculatus, extracted and purified by passing through a Sephadex LH-20 column.

\subsection{Meat instrumental quality}

The right longissimus thoracis et lumborum muscle was excised $24 \mathrm{~h}$ post mortem and the ultimate $\mathrm{pH}$ was determined by an Orion 210A pH-meter equipped with an Orion 9106 penetrating glass probe. Three-centimetre thick slices were then placed on polystyrene trays and were wrapped with a polyethylene film. The samples were allowed to bloom for $2 \mathrm{~h}$ and then colour $\left(\mathrm{L}^{*}, \mathrm{a}^{*}, \mathrm{~b}^{*}\right.$, Chroma and Hue angle) was measured by a Minolta CR300 colorimeter (Illuminant $\mathrm{D}_{65}$ ). To calculate cooking loss, weighed muscle samples were held in plastic bags and immersed in water at $75^{\circ} \mathrm{C}$ until the internal temperature of the meat reached $75^{\circ} \mathrm{C}$, as monitored by a probe. The bags were then placed under running cold water for $30 \mathrm{~min}$. The meat was then patted dry with paper towels and reweighed. Shear force was calculated on meat samples cooked as above. Three strips $(1 \times 1 \mathrm{~cm})$ were removed from each sample parallel to the muscle fibres and sheared perpendicularly to the direction of the fibres using an Instron 4411 apparatus equipped with a Warner-Bratzler shearing device. The speed was $100 \mathrm{~mm} \cdot \mathrm{min}^{-1}$. The right hind leg was also excised and dissected in order to determine the percentage of lean, bone and fat. For chemical analysis, raw meat was minced in a blender and AOAC [1] methods were used to measure moisture (39.1.02), fat (39.1.05) and ash (39.1.09). Protein was estimated by the difference.

\subsection{Meat sensory evaluation}

The sensory evaluation was conducted as described by Lanza et al. [9] and the same 10 panellists were involved in this trial as in [9]. Briefly, longissimus lumborum samples were cooked in a boiling water bath until the internal temperature reached $75^{\circ} \mathrm{C}$. The samples were served warm to the panellists that scored using a 9-point intensity scale for flavour, tenderness, juiciness and overall acceptability.

\subsection{Statistical analysis}

A first analysis of all data included the covariance for the body weight at 50 days. For the variables in which the covariance was not significant $(P>0.05)$, this was removed from the model and a t test was used to compare the two treatments. For the sensory evaluation, we used a two way ANOVA with diet and panellist as factors.

\section{RESULTS}

The experimental diet contained $17.5 \%$ crude protein, $35.3 \% \mathrm{NDF}$ and $2.1 \% \mathrm{CT}$ (Tab. I).

The lambs fed the P40 diet performed better than those fed the P10 diet with an average daily gain of $172 \mathrm{vs} .116 \mathrm{~g} \cdot \mathrm{d}^{-1}$ $(P<0.05)$ and obtained higher live weights at slaughter $(P=0.08)$ although the dry matter intake was not different between the treatments (Tab. II). The increased level of PEG from 10 to $40 \mathrm{~g} \cdot \mathrm{kg}^{-1}$, allowed a higher dry matter digestibility $(P=0.07)$ and a N and NDF digestibility decidedly higher 
Table II. Lamb growth performance and digestibility.

\begin{tabular}{|c|c|c|c|c|}
\hline Item & $\mathrm{P} 10$ & $\mathrm{P} 40$ & SEM & $P$-value \\
\hline No. of lambs & 7 & 7 & - & - \\
\hline $\mathrm{BW}$ at $50 \mathrm{~d}(\mathrm{~kg})$ & 13.1 & 13.1 & 0.49 & 0.989 \\
\hline BW at slaughter ${ }^{1}(\mathrm{~kg})$ & 19.4 & 21.7 & 0.10 & 0.079 \\
\hline $\operatorname{ADG}(50-100 \mathrm{~d})(\mathrm{g})$ & 116 & 172 & 14.70 & 0.049 \\
\hline $\operatorname{DMI}^{1}\left(g \cdot d^{-1}\right)$ & 774 & 863 & 61.20 & 0.319 \\
\hline DM digestibility (\%) & 62.6 & 66.3 & 1.04 & 0.073 \\
\hline $\mathrm{N}$ digestibility (\%) & 63.7 & 71.2 & 1.48 & 0.004 \\
\hline NDF digestibility ${ }^{1}(\%)$ & 31.6 & 40.8 & 2.04 & 0.009 \\
\hline DMI/live weight gain $\left(\mathrm{kg} \cdot \mathrm{kg}^{-1}\right)$ & 7.5 & 5.1 & 0.66 & 0.088 \\
\hline
\end{tabular}

${ }^{1}$ For these items, analysis of covariance for BW at 50 days was significant $(P<0.05)$ and was included in the model. Means are intended as adjusted means.

P10 and P40: see Table I.

BW: body weight, ADG: average daily gain, DMI: dry matter intake, N: nitrogen, NDF: neutral detergent fibre, SEM: standard error of the mean.

$(P<0.01)$ in the $\mathrm{P} 40$ lambs compared to the $\mathrm{P} 10$ group. The P10 lambs required an average dry matter intake of $7.5 \mathrm{~kg}$ to attain $1 \mathrm{~kg}$ of body weight gain, while the P40 lambs consumed $5.1 \mathrm{~kg}$ of dry matter to attain the same gain $(P=0.09)$.

Data at slaughter are presented in Table III. Carcasses from the P40 lambs were heavier than those from the P10 lambs $(P<0.05)$. The carcass yield was not significantly different between the groups. Carcasses from the P40 lambs showed a higher fatness score as judged by the visual classification $(P<0.05)$. However dissection of the hind leg did not indicate differences for the percentage of lean, fat and bone between the two treatments.

Meat ultimate $\mathrm{pH}$ was not different between the treatments. Meat colour was affected by the level of PEG in the diet since the P10 lambs showed higher $(P<0.05)$ values of lightness ( $\left.\mathrm{L}^{*}\right)$ compared to the P40 lambs. Meat from the P10 lambs tended to have higher moisture percentages $(P=0.06)$ and lower crude fat contents $(P=0.11)($ Tab. III $)$.
Sensory evaluation (Tab. IV) did not show any significant difference of flavour, tenderness and juiciness of the samples from the two treatments; the meat from the P10 lambs was considered as acceptable as the meat from the P40 lambs.

\section{DISCUSSION}

Considering a feed dry matter of $88.9 \%$ containing $2.1 \%$ of $\mathrm{CT}$, with the $\mathrm{P} 10$ diet, PEG supplied 0.54 times the CT content, while in the P40 diet it was 2.14 times the CT content. In the preceding trial [11], to eliminate the effect of CT in a diet containing the same ingredients, we supplied a quantity of PEG corresponding to 1.79 times the amount of CT as measured by the same method of Terrill et al. [16] applied in this trial. Silanikove et al. [14] and Ben Salem et al. [4] found that sheep given respectively carob leaves or Acacia cyanophylla leaves, improved their performance favourably when about 25 g PEG were supplied daily. 
Table III. Lamb carcass and meat instrumental quality.

\begin{tabular}{|c|c|c|c|c|}
\hline Item & P10 & $\mathrm{P} 40$ & SEM & $P$-value \\
\hline No. of lambs & 7 & 7 & - & - \\
\hline Carcass weight $^{1}(\mathrm{~kg})$ & 7.98 & 9.20 & 0.52 & 0.049 \\
\hline Carcass yield ${ }^{1}$ (\% empty live weight) & 47.91 & 49.38 & 0.70 & 0.212 \\
\hline Carcass fatness $^{1}$ (score) & 6.42 & 8.29 & 0.50 & 0.023 \\
\hline Hind leg lean $(\%)$ & 57.46 & 59.89 & 0.95 & 0.212 \\
\hline Hind leg fat (\%) & 10.63 & 12.19 & 0.69 & 0.273 \\
\hline Hind leg bone (\%) & 31.93 & 27.91 & 1.42 & 0.165 \\
\hline \multicolumn{5}{|l|}{ Meat instrumental quality } \\
\hline Ultimate $\mathrm{pH}$ & 5.96 & 5.79 & 0.06 & 0.136 \\
\hline Lightness $^{1}\left(\mathrm{~L}^{*}\right)$ & 49.16 & 46.14 & 0.90 & 0.037 \\
\hline Redness $\left(\mathrm{a}^{*}\right)$ & 15.90 & 14.51 & 0.50 & 0.176 \\
\hline Yellowness (b*) & 7.69 & 6.40 & 0.50 & 0.206 \\
\hline Chroma & 17.72 & 15.89 & 0.63 & 0.152 \\
\hline Hue angle & 25.48 & 23.69 & 1.15 & 0.460 \\
\hline Cooking loss $(\%)$ & 18.50 & 18.81 & 0.77 & 0.846 \\
\hline Warner-Bratzler shear force $\left(\mathrm{kgF} \cdot \mathrm{cm}^{-2}\right)$ & 3.32 & 4.29 & 0.31 & 0.116 \\
\hline \multicolumn{5}{|l|}{ Meat chemical composition } \\
\hline Moisture $^{1}(\%)$ & 78.06 & 76.63 & 0.45 & 0.062 \\
\hline Crude fat ${ }^{1}$ ( $\%$ wet weight) & 0.94 & 1.18 & 0.09 & 0.108 \\
\hline Ash (\% wet weight) & 1.12 & 1.12 & 0.01 & 1.000 \\
\hline Protein (\% wet weight) & 19.88 & 21.07 & 0.39 & 0.395 \\
\hline
\end{tabular}

${ }^{1}$ For these items analysis of covariance for BW at 50 days was significant $(P<0.05)$ and was included in the model. Means are intended as adjusted means.

P10 and P40: see Table I, SEM: standard error of the mean.

The Comisana is a dairy sheep breed and the growth rate of the lambs fed the $\mathrm{P} 40$ diet was similar to that attained by the lambs of this breed [8] fed a pelleted diet based on maize, barley and soybean meal and wheat straw. The P10 group, however, showed a worse performance, indicating a negative effect of carob CT. Evidently a PEG/CT ratio of 0.54 was not sufficient to eliminate all the negative effects of the carob tannins. However, $116 \mathrm{~g} \cdot \mathrm{d}^{-1}$ of daily gain obtained by the P10 lambs in this trial, was decidedly better than the $48 \mathrm{~g} \cdot \mathrm{d}^{-1}$ obtained in the preceding trial [11] by lambs fed a diet with the same ingredients at the same proportions but with no PEG supply.

One of the typical negative effects of dietary CT is the reduction of voluntary feed intake [12]. Increasing of voluntary feed intake when PEG is supplied in diets containing CT from carob leaves has been reported 
Table IV. Sensory analysis results (1- to 9-point scale).

\begin{tabular}{lcccc}
\hline Item & P10 & P40 & SEM & $P$-value \\
\hline No. of lambs & 7 & 7 & - & - \\
Flavour & 5.97 & 6.27 & 0.17 & 0.243 \\
Tenderness & 6.90 & 6.64 & 0.15 & 0.346 \\
Juiciness & 6.36 & 6.64 & 0.17 & 0.320 \\
Overall acceptability & 6.26 & 6.30 & 0.16 & 0.878 \\
\hline
\end{tabular}

P10 and P40: see Table I, SEM: standard error of the mean.

in both goats and sheep $[13,14]$. In the preceding trial [11], the supply of PEG increased intake by $60 \%$ compared to lambs not receiving the PEG supplementation. In the current trial the lower percentage of PEG enabled the P10 lambs to have similar intakes as the P40 lambs.

CT from carob pods have been reported to depress the intestinal activity of digestive enzymes [15]. The higher $\mathrm{N}$ digestibility $(P<0.01)$ of the $\mathrm{P} 40$ lambs demonstrates the effect of CT on digestion, compared to lambs supplemented with a lower level of PEG (P10). In this trial the improvement of $\mathrm{N}$ digestibility between $\mathrm{P} 10$ and $\mathrm{P} 40$ lambs was the $11.8 \%$. Addition of $40 \mathrm{~g}$ PEG per kg feed in our previous trial involving similar diets [11] increased $\mathrm{N}$ digestibility by $29.4 \%$ as compared with lambs given the same diet without PEG. In this trial, as well as in previous work with carob pulp for sheep [11], the CT depressed NDF digestibility to very low values. The low level of PEG supplementation resulted in a similar low NDF digestibility as previously fed unsupplemented diets [11]. There were differences between the trials in NDF digestibility with $40 \mathrm{~g}$ PEG per $\mathrm{kg}$ feed: $40.8 \%$ and $61.6 \%$ respectively in this and the previous trial [11].

The carcasses from the P40 lambs were heavier than those from the P10 animals reflecting the differences in growth rate and body weight at slaughter. Reduced carcass fatness in the P10 lambs reflected the re- sults obtained in animals fed a CT-containing diet without PEG as reported in the previous trial [11]. However in this experiment, the small amount of PEG supplied (P10) resulted in a similar tissue composition of the hind legs for both levels of PEG supplementation. In contrast, lambs not receiving PEG in the previous trial [11] had higher bone and lower fat percentages compared to the animals receiving $40 \mathrm{~g}$ of PEG per kg of the diet.

Reduced meat lightness has been reported when the effects of CT, from carob pulp or Acacia cyanophylla leaves, have been reduced by the addition of PEG. The removal of the CT effects seem to be correlated with an increased utilisation of the absorbed iron for synthesis of myoglobin [10, $11]$.

In the preceding trial [11], the animals not receiving PEG supplementation gave a meat with a higher ultimate $\mathrm{pH}$ and a reduced flavour and overall acceptability as judged by the panellists. In the present trial the even low supplementation of PEG was sufficient to obtain samples with similar values of $\mathrm{pH}$ and comparable meat sensory attributes.

\section{CONCLUSIONS}

This trial was designed to verify the possibility that reducing PEG supplementation 
in a diet containing $\mathrm{CT}$ fed to lambs would achieve adequate lamb growth, and carcass and meat quality. In a preceding trial [11], we found a diet based on carob pulp (56\% as fed) and supplemented with $40 \mathrm{~g}$ of PEG per $\mathrm{kg}$ of feed resulted in significant improvements of lamb growth and carcass and meat quality, compared to the animals fed the same diet without the addition of PEG. In this trial we demonstrated that a reduction in PEG supplementation from 40 to $10 \mathrm{~g} \cdot \mathrm{kg}^{-1}$ of feed, enabled good growth and digestion. Performance was lower than that of lambs supplemented with $40 \mathrm{~g}$ PEG per $\mathrm{kg}$ feed, but meat quality was similar for both treatments.

\section{ACKNOWLEDGMENTS}

This research was founded by the Italian Ministry of University and Scientific Research. Many thanks to Dr. G.C. Waghorn (AgResearch, Palmerston North, New Zealand) for suggestions during the trial and for $\mathrm{CT}$ analysis.

\section{REFERENCES}

[1] AOAC, Association of Official Analytical Chemists, Official methods of Analysis, 16th ed., AOAC, Washington DC, 1995.

[2] Barry T.N., Manley T.R., Duncan S.J., The role of condensed tannins in the nutritional value of Lotus pedunculatus for sheep. 4. Sites of carbohydrate and protein digestion as influenced by dietary reactive tannin concentration, Brit. J. Nutr. 55 (1986) 123-137.

[3] Ben Salem H., Atti N., Priolo A., Nefzaoui A., Polyethylene glycol in concentrate or feed blocks to deactivate condensed tannins in Acacia cyanophylla Lindl. foliage. 1. Effects on intake, digestion and growth by Barbarine lambs, Anim. Sci. 75 (2002) 127-135.

[4] Ben Salem H., Nefzaoui A., Ben Salem L., Tisserand J.L., Deactivation of condensed tannins in Acacia cyanophylla Lindl. foliage by polyethylene glycol in feed blocks. Effect on feed intake, digestibility, nitrogen balance, microbial synthesis and growth by sheep, Livest. Prod. Sci. 64 (2000) 51-60.

[5] Dransfield E., Nute G.R., Hogg B.W., Walters B.R., Carcass and eating quality of ram, castrated ram and ewe lambs, Anim. Prod. 50 (1990) 291-299.

[6] Goering H.D., Van Soest P.J., Forage fiber analysis (apparatus, reagents, procedures and some applications), Agricultural handbook No. 37, ARS, USDA, Washington DC, 1970, pp. 1-20.

[7] Jones W.T., Mangan J.L., Complexes of the condensed tannins of sainfoin (Onobrychis viciifolia Scop.) with fraction 1 leaf protein and with submaxillary mucoprotein, and their reversal by polyethylene glycol and $\mathrm{pH}, \mathrm{J}$. Sci. Food Agric. 28 (1977) 126-136.

[8] Lanza A., Pennisi P., Licitra G., Avondo M., Effetti delle variazioni del livello alimentare nella produzione dell'agnellone leggero di razza Comisana. 1. Rilievi in vita e alla macellazione, Zootech. Nutr. Anim. 17 (1991) 347-354.

[9] Lanza M., Priolo A., Biondi L., Bella M., Ben Salem H., Replacement of cereal grains by orange pulp and carob pulp in faba-bean based diets fed lambs: effects on growth performance and meat quality, Anim. Res. 50 (2001) 21-30.

[10] Priolo A., Ben Salem H., Atti N., Nefzaoui A., Polyethylene glycol in concentrate or feed blocks to deactivate condensed tannins in Acacia cyanophylla Lindl. foliage. 2. Effects on meat quality of Barbarine lambs, Anim. Sci. 75 (2002) $137-140$.

[11] Priolo A., Waghorn G.C., Lanza M., Biondi L., Pennisi P., Polyethylene glycol as a means for reducing the impact of condensed tannins in carob pulp: effects on lamb growth performance and meat quality, J. Anim. Sci. 78 (2000) 810-816.

[12] Reed J., Nutritional toxicology of tannins and related polyphenols in forage legumes, J. Anim. Sci. 73 (1995) 1516-1528.

[13] Silanikove N., Gilboa N., Nir I., Perevolotsky A., Nitsan Z., Effect of a daily supplementation of polyethylene glycol on intake and digestion of tannin-containing leaves (Quercus calliprinos, Pistacia lentiscus and Ceratonia siliqua) by goats, J. Agric. Food Chem. 44 (1996) 199-205. 
[14] Silanikove N., Nitsan Z., Perevolotsky A., Effect of a daily supplementation of polyethylene glycol on intake and digestion of tannin-containing leaves (Ceratonia siliqua) by sheep, J. Agric. Food Chem. 42 (1994) 2844-2847.

[15] Silanikove N., Perevolotsky A., Provenza F.D., Use of tannin-binding chemicals to assay for tannins and their negative postingestive effects in ruminants, Anim. Feed Sci. Technol. 91 (2001) 69-81.

[16] Terrill T.H., Rowan A.M., Douglas G.B., Barry T.N., Determination of extractable and bound condensed tannins concentrations in forage plants, protein concentrate meals and cereal grains, J. Sci. Food Agric. 58 (1992) 321-329.

[17] Waghorn G.C., Jones W.T., Shelton I.D., McNabb W.C., Condensed tannins and the nutritive value of herbage, Proc. N. Z. Grass. Ass. 51 (1990) 171-176.

[18] Waghorn G.C., Reed J.D., Ndlovu L.R., Condensed tannins and herbivore nutrition, in: Buchanan-Smith J.G., Bailey L.D., McCaughy P. (Eds.), Proceedings of the 18th International Grassland Congress, Association Management Centre, Calgary, AB, 1999, pp. 153-166 (Volume iii). 
